\title{
一般論文
}

\section{Removal of Colloidal Silica from Water with Anion Exchange Resins}

\author{
Wataru AGUI, Hirobumi SHIMOYAMADA, \\ Masahiko ABE, ,** and Keizo OGINO,,**
}

\author{
Rohm and Haas, Japan Research Center, 2763, Happo, Washinomiya-machi, \\ Kita-Katsushika-Gun, Saitama 340-02 \\ *Faculty of Science and Technology, Science University of Tokyo \\ 2641 Yamazaki, Noda-shi, Chiba 278 \\ **Institute of Colloid and Interface Science, Science University of Tokyo \\ 1-3, Kagurazaka, Shinjuku-ku, Tokyo 16
}

(Accepted October 5, 1993)

\begin{abstract}
Summary
This study describes the dissolved state of colloidal silica in water and its adsorption properties on anion exchange resins (AERs). A colloidal silica solution of $3 \%$ was prepared by ion exchange resin method from a sodium silicate solution. The colloidal silica in water formed about $10 \mathrm{~nm}$ particles in diameter. When leaving the colloidal silica solution at less than $\mathrm{pH}=7$, the gelation was occurred. The gelation rate became the fastest at $\mathrm{pH}=5.2$. The adsorption properties of colloidal silica on various AERs were investigated in batch adsorption. When added strong base anion exchange resins (SBAERs) to the colloidal silica solutions of about $560 \mu \mathrm{g} / \mathrm{mL}$ as $\mathrm{SiO}_{2}$, the colloidal silica concentration in water decreased rapidly, at the same time, ionic silica was newly generated on the resin surface. The total amounts of silica removed by SBAERs became larger than the stoichiometrically removable amount of ionic silica by them. According to the scanning electron microscopic observation, colloidal silica adsorbed on the surface of SBAERs became to dissolve to the resin inside with the elapse of time. These results suggest that colloidal silica adsorbed on SBAERs should exist in concentrated state inside of the resins and in ionic silica at the ion exchange sites.
\end{abstract}

\section{Introduction}

In the production of highly purified water used for the advanced and sophisticated industries, such as atomic power and semiconductor industries, removal of silica from water is a key concern. Power plants seek to minimize deposition of colloidal silica on the inside wall of equipment. Meanwhile, colloidal silica destroys the electric performance of wafers if deposited on the wafer's surface ${ }^{1,2)}$. Ion exchange resins are indispensable for demineralization of water. Ionic silica in water is effectively removed by SBAERs. However, colloidal silica present in raw water is 
difficult to remove from water with them. There are few papers on the removal of colloidal silica ${ }^{3), 4}$. In addition, it is reported that under certain conditions silica can polymerize in ion exchange beds to from colloidal silica ${ }^{5}$.The mechanism has not been elucidated. The objective of this study is to investigate the adsorption properties of colloidal silica on various AERs and to make clear the removal mechanism by them.

\section{Experimental}

\section{Preparation of colloidal silica}

Five grams of reagent grade of sodium silicate (Wako Pure Chemicals Industries,Ltd., Osaka, Japan) was dissolved in $100 \mathrm{~mL}$ of silica free pure water (total silica concentration is less than $1 \mathrm{ppb}$ ). $2 \mathrm{~mL}$ of H-form SACER (Amberlite IR-120B) was added into the solution at intervals of every $15 \mathrm{~min}$ with stirring at $25^{\circ} \mathrm{C}$. Addition of the SACER was repeated until the $\mathrm{pH}$ and conductivity values of the solution became constant. Then the solution was filtered by a $0.22 \mu \mathrm{m}$ membrane filter (MF). The colloidal silica concentration was adjusted to $3 \%$ by diluted with pure water.

\section{Determination of colloidal silica}

Inductively coupled plasma atomic emission spectrometry (ICP-AES, SPS-7000, Seiko Instruments Inc., Tokyo, Japan) was used to determine the total silica concentration in water. The ionic silica concentration in water was measured by the molybdate method $^{6}$. Then, the colloidal silica concentration was calculated as the difference of both concentrations.

\section{Particle size measurement of colloidal silica in water}

The particle size of colloidal silica was measured by dynamic light scattering using 4700 Submicron Particle Analyzer (Light source; Ar laser, Wave length; $488 \mathrm{~nm}$, Temperature; $25^{\circ} \mathrm{C}$, Malvern Co., Ltd., Worcestershine, England).

\section{Preparation of AERs}

All ion exchange resins used here are products of Rohm and Hass company (Philadelphia, USA). AERs used in adsorption experiments have different functional groups and skeltal structures as shown in Table 1. These resins were regenerated by the ordinary regeneration methods and dehydrated for $48 \mathrm{~h}$ at 25 ${ }^{\circ} \mathrm{C}$ under reduced pressure.

\section{Adsorption isotherms of colloidal silica}

A suitable amount of each AER was weighed out each in a $100 \mathrm{~mL}$ Erlenmeyer flask. $25 \mathrm{~mL}$ of colloidal silica solutions of various concentrations were added into the flasks and the mixtures were stirred for $24 \mathrm{~h}$ at $25^{\circ} \mathrm{C}$ during which equilibrium was confirmed. Then, the mixtures were filtered with a

Table 1 Characteristics of AERs.

\begin{tabular}{cccc}
\hline AER & Structure & Type & Matrix \\
\hline IRA-402BL & Gel & I & Hydrophobic \\
410 & Gel & II & Hydrophobic \\
900 & MR & I & Hydrophobic \\
938 & MR & I & Hydrophobic \\
910 & MR & II & Hydrophobic \\
93 & MR & W & Hydrophobic \\
\hline MR: Macroreticular & & I : $-\mathrm{N}^{+}\left(\mathrm{CH}_{3}\right)_{3}$ & II : $-\mathrm{N}^{+}\left(\mathrm{CH}_{3}\right)_{2} \mathrm{C}_{2} \mathrm{H}_{4} \mathrm{OH}$ \\
$(\mathrm{Basicity}: \mathrm{I}>\mathrm{II})$ & \\
& & W: $-\mathrm{N}^{+}\left(\mathrm{CH}_{3}\right)_{2}$
\end{tabular}


$0.22 \mu \mathrm{m} \mathrm{MF}$ and the total silica concentrations in the filtrates were measured by ICP. The adsorption amount of colloidal silica on each AER was determined by the difference of the total silica concentration before and after adsorption.

\section{SEM observation of SBAER surface after adsorption of colloidal silica}

Commercially available colloidal silica (Carplex FPS-5, Shionogi pharmaceutical Co., Japan) was used. The assay of $\mathrm{SiO}_{2}$ is $92.0-98.0 \%$. The colloidal silica of $2.5 \mathrm{mg}$ was put in $100 \mathrm{~mL}$ of silica free pure water in a $300 \mathrm{~mL}$ Erlenmeyer flask. IRA-402BL of $\mathrm{OH}$ form of $200 \mathrm{mg}$ was placed in the flask. The mixture was stirred gently at $25^{\circ} \mathrm{C}$ and filtered by a $0.45 \mu \mathrm{m} \mathrm{MF}$ at definite time intervals. The SBAER on the MF was dried at $60^{\circ} \mathrm{C}$ for $30 \mathrm{~min}$ and the resin surface was observed by scanning electron microscope (SEM, JSM-5400LV, JEOL, Japan).

\section{Results and discussion}

\section{Dissolved state of colloidal silica prepared}

The ion exchange method in batch used in this work seemed to bring about the formation of more uniform colloidal silica than the column method". The profile of the formation of colloidal silica is shown in Fig. $\mathbf{1}$ in the relation of the conductivity and

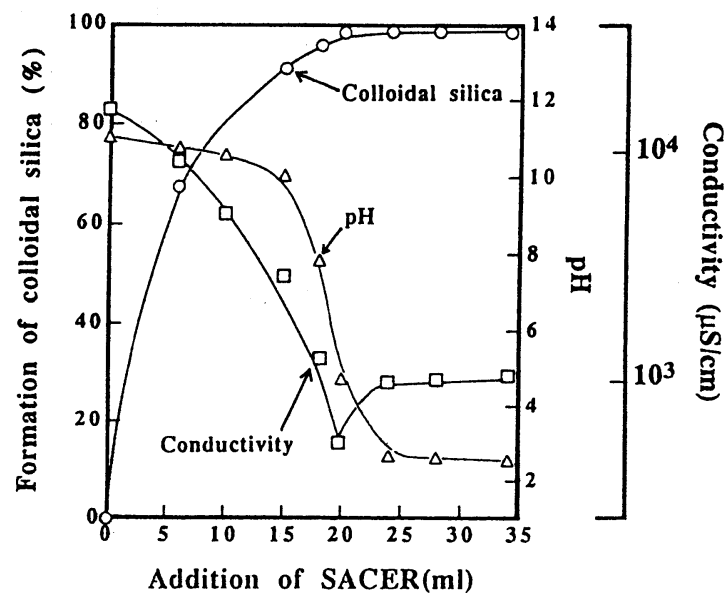

Fig.1 Relationship between formation of colloidal silica and $\mathrm{pH}$ and conductivity by addition of IR-120B (H-form) at $25^{\circ} \mathrm{C}$.
$\mathrm{pH}$ of the sodium silicate solution and the added amount of SACER. Sodium ions were gradually exchanged with $\mathrm{H}^{+}$ions on the resin. As a result, colloidal silica was slowly formed. At the addition of SACER of $20 \mathrm{~mL}$, the $\mathrm{pH}$ of the solution indicated 5.2 and the conductivity became minimum. This means the completion of the colloidal silica formation. Then, the conductivity and $\mathrm{pH}$ of the solution became constant at $1.1 \times 10^{3} \mu \mathrm{S} / \mathrm{cm}$ and 2.6 , respectively. The particle size distribution of colloidal silica prepared was pretty narrow in $6 \sim 13 \mathrm{~nm}$. The average particle size was about $10 \mathrm{~nm}$ in diameter. When the colloidal silica solutions were allowed to stand in various $\mathrm{pH}$, the particle of silica colloid grew gradually as described in Fig.2. Finally, gelation of colloidal silica was occurred. The gelation rate became the fastest at $\mathrm{pH}$ 5.2. However, the colloidal silica solution was stabilized in the weak alkali by adjusting $\mathrm{pH}$ with $\mathrm{NaOH}$. In our adsorption experiments of colloidal silica, tests were carried out immediately after preparing the colloidal silica solution excluding $\mathrm{NaOH}$.

\section{Adsorption isotherms of colloidal silica on AERs}

Fig.3 shows the adsorption isotherms of colloidal silica on SBAERs with trimethylamine functional

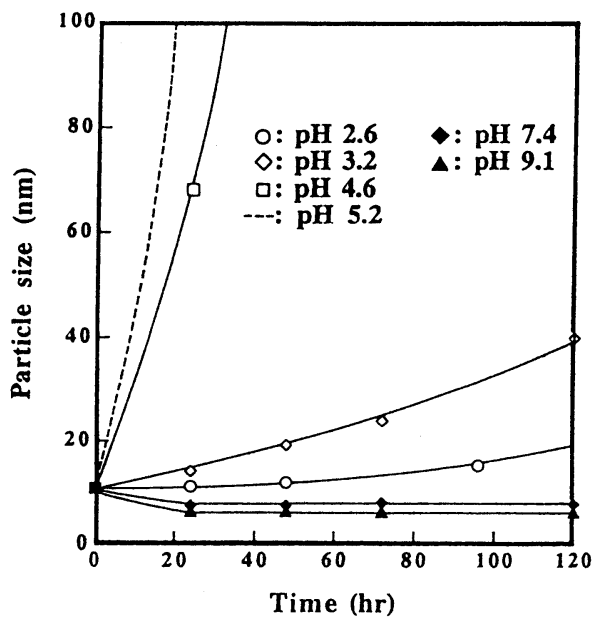

Fig.2 Change of particle size of colloidal silica with the elapse of time at $25^{\circ} \mathrm{C}$. 


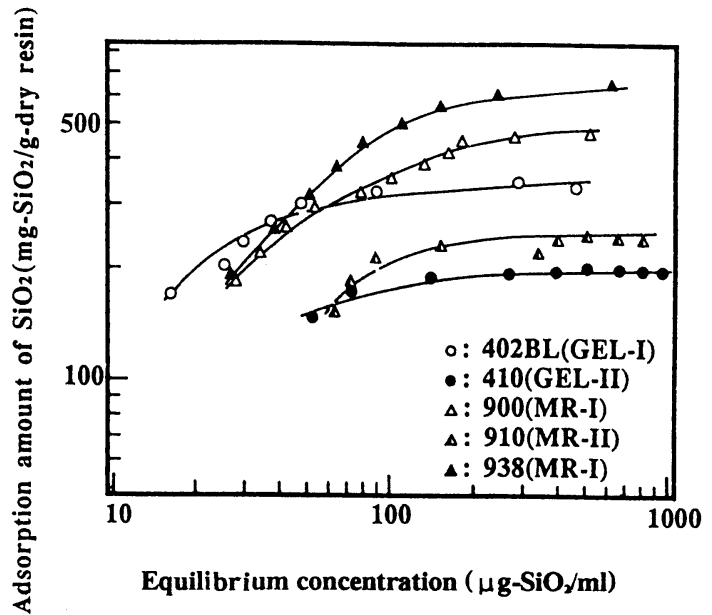

Fig.3 Adsorption isotherms of colloidal silica on SBAERs at $25^{\circ} \mathrm{C}$.

group (type I) and with dimethylethanolamine functional group (type II), varing the skeltal structure of resins. As clearly found, SBAERs of type I, which has higher basicity, adsorbed colloidal silica more than those of type $I I$. MR type resins especially having pores seemed to give larger adsorbed amounts of colloidal silica than GEL type resins. The pore sizes of IRA-900 and IRA-938 range predominantly in about $140-220 \mathrm{~nm}$ and $2.5 \sim 23 \mu \mathrm{m}$ in diameter ${ }^{8,9)}$. This indicates that GEL type SBAERs substantially without pore should adsorb colloidal silica on the resin surface and MR type resins with pores adsorb it not only on the surface but also in the pores.

It was also found that weak base anion resins were not effective to remove colloidal silica from water, as given in Fig.4.

\section{Adsorption mechanism of colloidal silica on SBAERs}

\subsection{Effect of SBAERs on colloidal silica in water}

The effect of SBAERs on colloidal silica dissolved in water was investigated. A SBAER of $100 \mathrm{mg}$ was added to the colloidal silica solution $(560 \mu \mathrm{g} / \mathrm{mL}$ as $\mathrm{SiO}_{2}$ ) of $25 \mathrm{~mL}$. As shown in Fig.5, the total silica concentration rapidly decreased to $10 \mu \mathrm{g} \mathrm{SiO} / / \mathrm{mL}$. Ionic silica was newly generated and its concentration gradually increased to $50 \mu \mathrm{g} / \mathrm{mL}$ as $\mathrm{SiO}_{2}$ in $1 \mathrm{~h}$. These results show that colloidal silica dissociates to

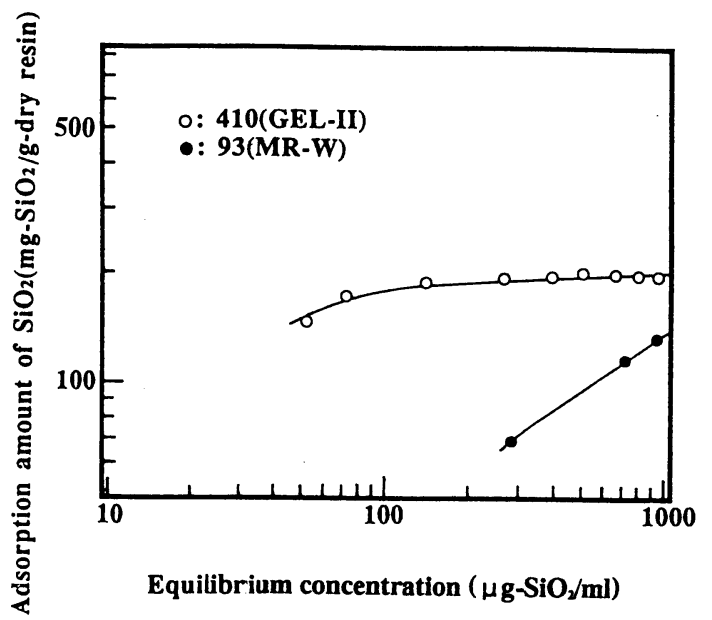

Fig.4 Adsorption isotherms of colloidal silica on SBAERs at $25^{\circ} \mathrm{C}$.

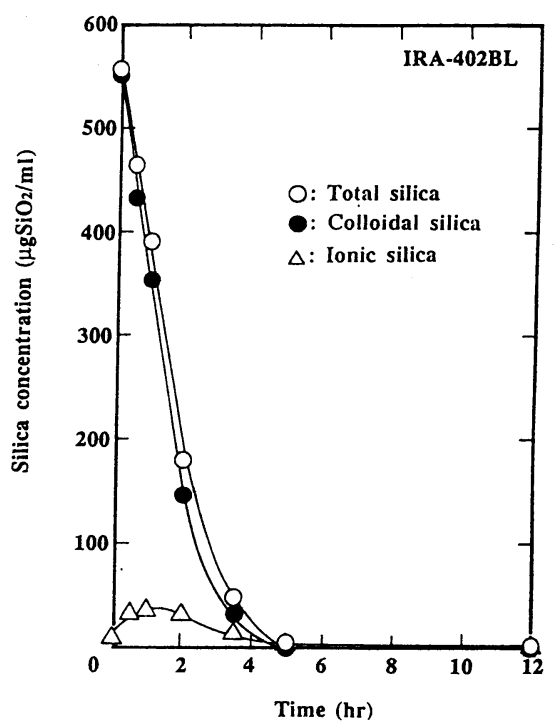

Fig.5 Change of silica concentration by addition of IRA-402BL.

form ionic silica on the surface of $\mathrm{OH}$ form resins with strong alkali. The $\mathrm{pH}$ of the solution changed from 5.3 to 6.8 . The total amount $(4.5 \mathrm{meq} / \mathrm{g}-\mathrm{R})$ of silica removed on the resin became larger than that (3.7meq/g-R) of ion exchange capacity. On the other hand, SBAERs of salt form ( $\mathrm{Cl}$-form) did not show any effect on the behavior of colloidal silica in water. As shown in Fig.6, the amount of ionic silica generated by adding type II SBAER was larger than 
that by adding type I resin. This suggests that the rate of ion exchange reaction between $\mathrm{OH}$ group on the ion exchange site and ionic silica should be faster in type I than in type II .

In order to confirm the above statement, the reduction rate of ionic silica concentration was investigated by adding various SBAERs. As shown in Fig.7, the ionic silica concentration decreased faster in the solution to which type I resin with trimethy-

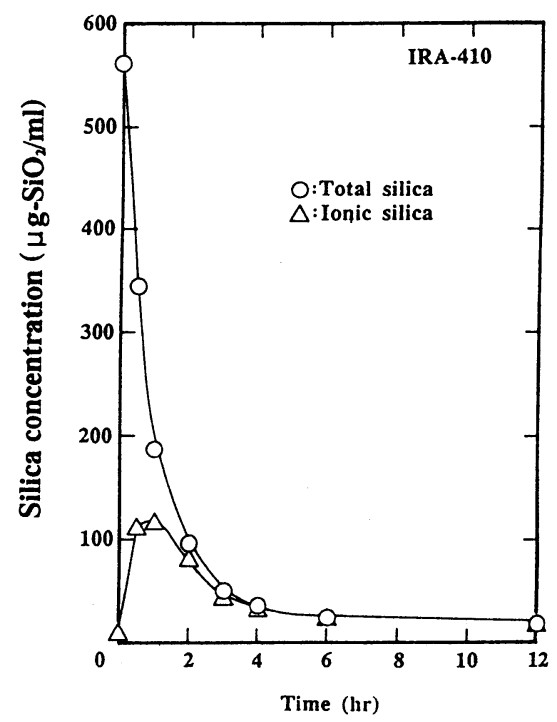

Fig.6 Change of silica concentration by addition of IRA-410.

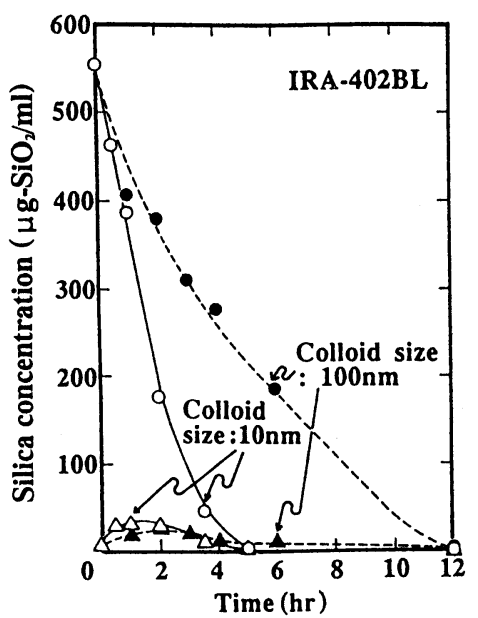

lamine functional group was added. In case of the addition of WBAERs, the decreasing rate of the colloidal silica concentration and the generating rate of the ionic silica concentration were much slower. Because they have lower basicity than others.

\subsection{Effect of particle size of colloidal silica}

The effect of the particle size of colloidal silica on the adsorption rate on SBAERs was checked. Colloidal silica solutions containing $10 \mathrm{~nm}$ and 100 $\mathrm{nm}$ particles in diameter were tested. The adsorption rate of the colloidal silica with larger particle size became slower on SBAERs. The result is shown in

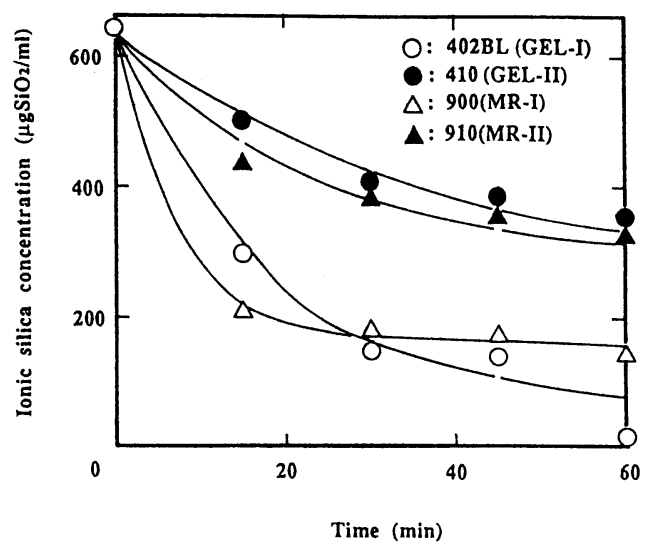

Fig.7 Change of ionic silica concentration by addition of SBAERs.

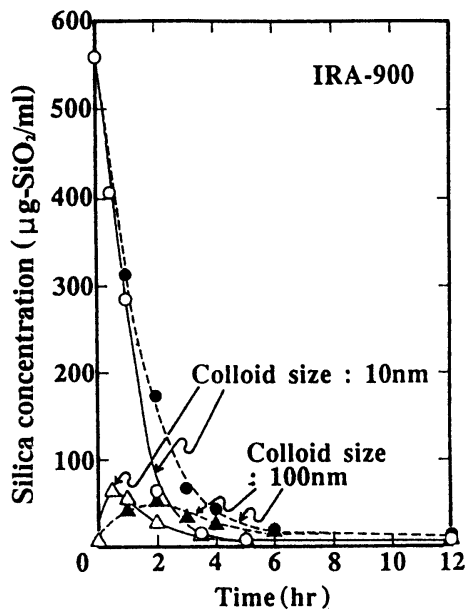

Fig.8 Effect of particle size of colloidal silica on adsorption on SBAERs. 
Fig.8. The generation rate of ionic silica on the resin surface also became slower in the larger particle size of colloidal silica. In addition, the decreasing rate of the total silica concentration was faster in MR SBAERs than in GEL ones. This indicates that MR resins with pores work effectively in removing colloidal silica.

\subsection{SEM observation of SBAER surface adsorbed colloidal silica}

The surface of SBAER (IRA-402BL, OH-form) adsorbed the colloidal silica (Carplex) was observed by SEM (Fig.9). The original surface of the resin was smooth and clean. When the resin was put in the colloidal silica solution, the resin surface was completely covered with colloidal silica coagulated with 20 30 nm particles. As time passed, the colloidal silica adsorbed on the surface seemed to move to the resin inside and finally to dissolve further inside of the resin. However, a small amount of colloidal silica still remained on the surface. Therefore, the total amounts of silica removed on the resin became larger than the ion exchange capacity. This phenomenon is similar to that of dissociation of crud on the surface of strong acid cation exchange resins ${ }^{10}$. The dissolved forms of silica in SBAERs will be investigated in future, using electron spectroscopy for chemical analysis (ESCA), X-ray analyzer and other advanced analytical instruments.

\section{Conclusions}

On the basis of the above results, the following conclusions were drawn.

1. Colloidal silica made by ion exchange method formed about $10 \mathrm{~nm}$ particles.

2. When leaving the colloidal silica in acidic conditions, the gelation was occurred.

3. MR resins with pores had larger adsorbed amounts of colloidal silica.

4. Colloidal silica was adsorbed well on the surface of SBAERs and at the same time dissociated to ionic silica to some extent.

5. Colloidal silica adsorbed on SBAERs became to dissolve to the resin inside.

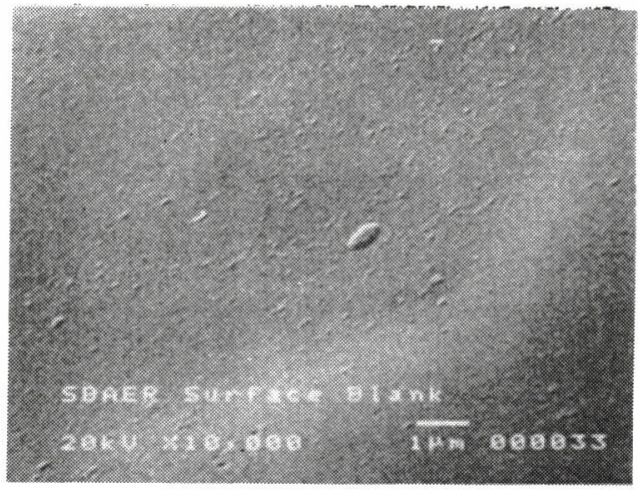

(b)

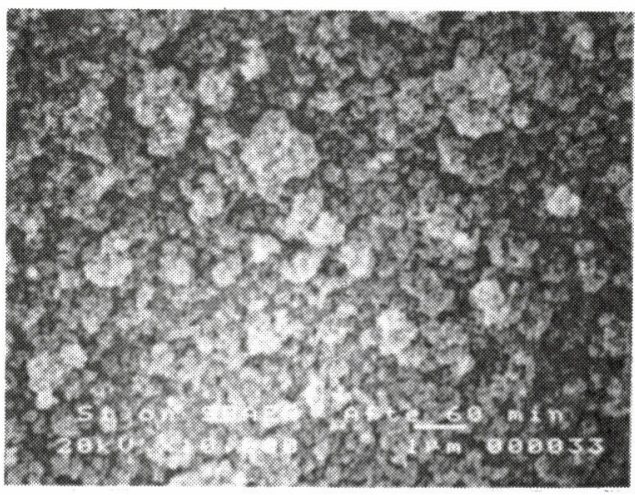

(c)

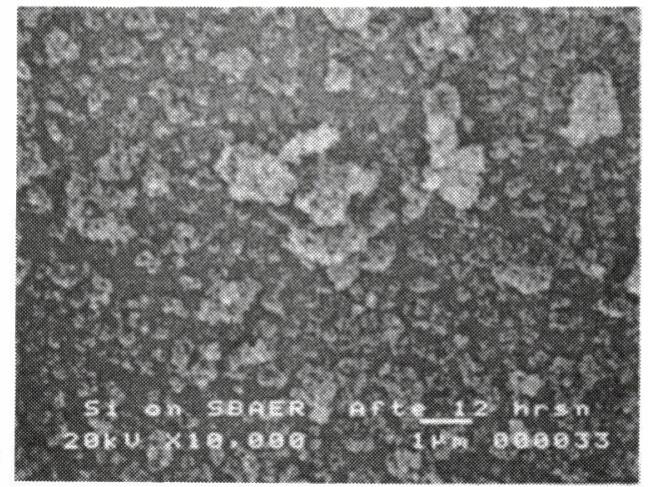

Fig.9 SEM micrographs on the surface of SBAER: (a)Original surface of IRA-402BL, (b)Just after adsorption of colloidal silica and (c) $12 \mathrm{~h}$ later.

6. SBAERs removed silica more than the ion exchange capacities at the equilibrium state in batch.

We thank Dr. J. H. Barrett, Director of Rohm and Haas Japan research Center, for his permission to submit this paper and also would like to thank Dr. $\mathrm{H}$. 
Kuyama, Senior Technical Adviser of the above research center, for his helpful disccussions.

\section{Reference}

1) M. Henley, Ultrapure Water December, (1992) p.13.

2) K. Pate and L. Hollister, Ultrapure Water Expo'93, (1993) p.1.

3) T. Kataoka and A. Muto, ICIE'91, Proceedings (1991) p.329.

4) E. Zaganniaris, S. Duolut and L. Morino, Reactive
Polymer, 17, 15 (1992).

5) B. J. Hoffman and M. J. Gavaghan, 4th Semiconductor Pure Water Conference, Transcripts (1985) p.3.

6) JIS K0555, (1990)

7) K. Ogino and I. Kuronuma, J. Colloid and Interface Science, 56, 629 (1976)

8) H. Kuyama, "Chelate Resin and Ion Exchange Resin", ed. by N. Hojo, Kodan-sha Scientific (1981) p. 150 .

9) Amberlite Catalog, issued by Organo, June (1987).

10) N. Higosaki, T. Yagihashi and T. Kagawa, Patent, Japan Kokai, Hei 5-15876.

\title{
水中に溶存するコロイド状シリカの \\ 各種陰イオン交換樹脂による除去
}

\author{
安居院 渡, 下山田 博文*, \\ 阿部 正彦***,荻野 圭三***, \\ ローム・アンド・ハース日本リサーチセンター イオン交換樹脂研究部 \\ 7340-02 埼玉県北葛飾郡蹵宮町八甫 2763 \\ *東京理科大学 理工学部 \\ 厂278 千葉県野田市山崎 2641 \\ **東京理科大学 界面化学研究所 \\ ₹162 東京都新宿区神楽坂 $1-3$
}

（1993年10月 5 日受理）

\section{要 旨}

純水製造において，水中に溶存するシリカの除去は重要な課題である。本報では，ケイ酸ナト リウム溶液からイオン交換法により調製したコロイド状シリカを用い，コロイド状シリカの水中 での溶存状態および各種陰イオン交換樹脂に対する吸着特性並びに吸着機構をバッチ法により検 討した。生成したコロイド状シリカの粒径は直径約 $10 \mathrm{~nm}$ であった。コロイド状シリカは強塩基性 陰イオン交換樹脂の表面および孔内部に吸着され, その際コロイド状シリカの一部はイオン状シ リカに解離することが分かった。強塩基性イオン交換樹脂により除去された全シリカ量は，吸着 平衡状態において樹脂のイオン交換容量以上であった。電子顕微鏡を用いた観察により，樹脂表 面に吸着されたコロイド状シリカは, 時間の経過に伴って樹脂内部に溶解していくことが分かっ た。 